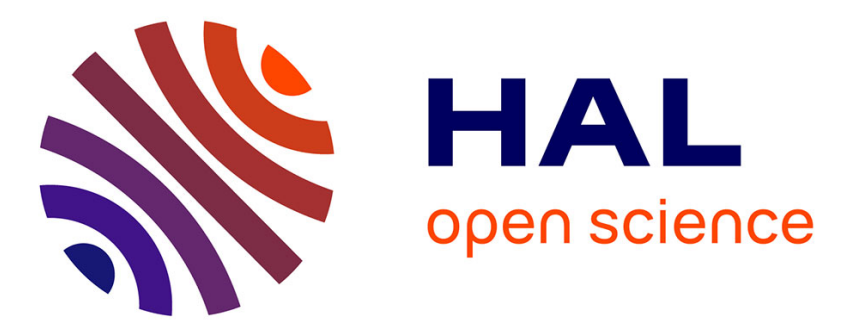

\title{
The discourse particle to and word ordering in Hindi: From grammar to discourse
}

\author{
Annie Montaut
}

\section{To cite this version:}

Annie Montaut. The discourse particle to and word ordering in Hindi: From grammar to discourse. Fernandez Vest Joceline \& Van Valin Robert. Information Structuring in Spoken Languages from a Cross-linguistic Perspective, 283, Benjamins, pp.263-82, 2015, Trends in Linguistics.Studies and Monographs. halshs-01287633

\section{HAL Id: halshs-01287633 \\ https://shs.hal.science/halshs-01287633}

Submitted on 14 Mar 2016

HAL is a multi-disciplinary open access archive for the deposit and dissemination of scientific research documents, whether they are published or not. The documents may come from teaching and research institutions in France or abroad, or from public or private research centers.
L'archive ouverte pluridisciplinaire HAL, est destinée au dépôt et à la diffusion de documents scientifiques de niveau recherche, publiés ou non, émanant des établissements d'enseignement et de recherche français ou étrangers, des laboratoires publics ou privés. 


\title{
The discourse particle to and word ordering in Hindi: From grammar to discourse
}

\author{
Annie MONTAUT INALCO-USPC, SeDyL UMR 8202, Labex EFL \\ annie.montaut@inalco.fr
}

In Information Structure and Spoken Language. Van Valin, Robert \& Fernandez-Vest Jocelyne (eds). 263-282. Amsterdam/New York: Benjamins.

\begin{abstract}
Word reordering is the most common way in Hindi for focalizing and thematizing a constituent, without morphological restructuration. A theme is thus fronted and a focus is preverbal. However, the language also displays other devices, namely particles, for this purpose, particularly but not only, for constituents already respectively fronted and preverbal in the unmarked order (SOV). The paper bears on the most frequent of such particles, the thematic enclitic particle to. Previous analyses have pointed to the extreme diversity of its meanings -- up to four "homonyms": intensive, contrastive, assertive, request particle. The present study explains this diversity in terms of a common operation which involves intersubjectivity. As a thematic particle, to requalifies the constituent as contrasting either with other elements present in the dialogue or with a view point on the constituent which has been previously expressed or attributed the other. Being highly sensitive to the exchange of distinct viewpoints, the particle may also cliticize to non-initial constituents, in which case it marks the whole statement as dismissing of opposing a previous proposal. The behaviour of the particle to may ultimately be traced to the other and older functions of the word used as a correlative pronoun and as a conjunction, which also presuppose an initial content as the starting point for a distinct predication or discourse sequence.
\end{abstract}

\section{Introduction}

The Hindi word to is both a conjunction ('so', 'then'), and a discourse clitic particle, both of which have usually been considered as different (homonymous) units. The discourse particle itself, described as intensive, vaguely contrastive (McGegor 1972: 141), or emphatic (Kellogg [1856] $1938: 490$ ), covers such a collection of highly distinct meanings ('sure, well, at least, finally, will you, but', etc.) that it too has been assumed to represent homonymous words (Shapiro 1999; Lakshmi Bai 1977). This study aims to show that the diversity of the surface meanings and functions of the latter (clitic particle) may be accounted for by a common abstract operation, implemented according to the various specific contexts of occurrence, both syntactic and enunciative (discursive). After a brief presentation of the grammatical to, always clause initial, in section 1, I will attempt in the following sections to disentangle the various factors (position and scope, intonation) at play in the scope of the discourse particle to, and show that the operation underlying all surface meanings, as a topic marker (section 2) and as the so-called contrastive marker (section 3), involves intersubjectivity. By connecting this abstract operation with the meaning of conjunctive to, we assume polysemy rather than homonymy as the more effective explanation of the various readings of to.

\section{From the conjunction to the theme marker}


The non-clitic to, strongly stressed, essentially behaves as a coordinative conjunction ('so', 'then'), and as a correlative, particularly in conditionals.

In the first case, to mostly operates as a linker between two discourse paragraphs, the second one still remaining in the logical sequence of the first one but adding to it a new element instead of a simple relation of cause-effect or of temporal sequence ${ }^{1}$ : it introduces a new turn or phase of the story in narrative contexts. It may also introduce a new idea or argument in an argumentative sequence, in the same way as its English equivalent 'then/so'.

Given the fact that to occurs at cardinal moments in a narration, for chaining a distinct episode or for shifting the frame or scenario or viewpoint, when a story teller interrupts his tale after a non-final event, the hearer who wishes to know what happens next (and is not predictable) usually maps his expectation by somewhat providing the empty frame for further instantiation, and he does so by using to (1a), a to which may even behave as sentential (1b):
(1) a

to $k y \bar{a} \quad h u \bar{a} ?$
to interr be.PFV
'And then what happened?'
b to ?
to
'And then?'

Using this to-sentence in interrogative contexts which do not convey interrogation regarding some following event as in (1b) is potentially polemical ( $c f$ English "so what?") with underlying aggressive denegation ("what does it prove? what does it amount to?"): such rhetorical interrogations indeed question the potential of the previous statement to provide a step for further innovative developments in a logical argument. Hence the polemical meaning, since it dismisses the relevance of what has just been said: the speaker A who uses this rhetorical to means that there is nothing to make out of what has been said, and that the information or argument given by the speaker B is nil. With to, A pretends to provide a frame to further instantiate, in order to mean that it has not been instantiated yet and cannot be:
(1)
c $A-a b h \bar{\imath}$ takmerā kām kiȳa nahīn? now.justtill POSS.1SG work.MSG do.PFV.MSG NEG
A - 'You still have not done my work (what I asked you to do)?'
$B$ - Sir, mere-pās das aur chiTThiyān āyīn... $\quad$ A- To ? Sir 1SG-near ten more letter.FPL come.PFV.FPL to B -'Sir, ten other letters came [I got much work]... A - So what ?'

The other main use of the non-clitic to is to introduce the apodosis after a conditional clause (agar/yadi: 'if'), in a correlative system typical of Indo-Aryan languages. ${ }^{2}$
a agar
tum
merī madad
karte
to main saphal
ho-jātā
if
my help
do.CTF
to $1 \mathrm{SG}$
successful
become.CFT

\footnotetext{
1 Two relations which can also be lexically expressed respectively by islie 'therefore' and phir 'after that', 'then'.

2 Cf. Montaut $(1999,2012)$. The correlative to can also correlate temporal dependent clauses (protasis introduced by jab 'when'), adding a nuance of cause-effect in contrast with the simply temporal $t a b$. It is also more frequent in iterative contexts, where a whole series is occurrence is scanned.
$\begin{array}{llll}\text { jab } & \bar{a} p & \log & \text { cale gae } \\ \text { when } & 2 \mathrm{H} & \text { people } & \text { leave go.PFV }\end{array}$
to /tab mainne usko bulā liyā
when $2 \mathrm{H}$ people leave

Abbreviations : ERG (ergative), ACC (accusative), DAT (dative), PFV (perfective: simple anterior), PFT (perfect), PRES (present), CTF (counterfactual), H (honorific), PPFT (pluperfect).
} 
'If you helped me [had helped me] I would succeed [would have succeeded]'

The term introducing the first element of the correlative dyptich is often omitted in Hindi but never is to, required in the hypothetic system even when the protasis is left unexpressed: 3

(2) $\mathrm{b}$ huī to...?

be.PFV.PL to

The correlative to in the conditional system is then a marker of entailment which chains the protasis $p$ to the apodosis $q$ in the way $p>q$ (you help me $>$ I succeed), but in such a situation where two divergent paths are available: $p^{\prime}$ (you do not help me) would entail $q^{\prime}$ (I do not succeed). The speaker presents an alternative, and the apodosis is constructed in leaving aside one of the possible scenarii. To corresponds to the selection of one of these two scenarii in contrast with the other one in a given situation where the speaker has constructed what Culioli (1999) calls a fictive landmark, that is, a point of localisation for the predication $q$ which is not real (not asserted) but virtual ("if": if we admit, let us imagine). ${ }^{4}$ It behaves as an indicator of contrastive selection triggering q by contrast with q'.

\subsection{A continuity from coordination and correlative to thematic particle?}

Whereas, as a correlative in conditional constructions, to involves the selection of one path in contrast with another one, as a coordinative conjunction, it opens a new sequence which resets the narrative flow on the basis of the previous statement, by shifting the scenery or the viewpoint, which makes the sequence following to distinctively salient.

The word etymologically stems from an ancient pronominal basis (Sanskrit $t a-$ ) referring to third person ('that', 'he'), which is still used as such in certain Indo-Aryan languages such as Marathi (to 'he') although not in Hindi..$^{5}$ This basis is typically used throughout Sanskrit, Prakrits and modern Indo-Aryan in the correlative system, as a linker between a relative clause (Sanskrit $y a-$ 'wh-') and its correlated clause. It is well known that anaphoric devices have often provided for coordinators in many languages (Brill \& Rebuschi 2006, Haspelmath 2004: 3-39), and their use as correlators results from the same logic.

As for the shift from correlative to discourse particle, the evolution from conditional markers into theme markers has also been well described (Haiman 1978, Haspelmath 2008: $1005 \mathrm{sq}$ ): the conditional clause (protasis) behaves as the frame for the following predication in the apodosis. Since in Hindi the correlator which introduces the apodosis, represents the end part (right position) of the protasis in truncated systems ( $c f$. ex $2 \mathrm{~d}$ ), it is all the more understandable that it came to be used as a topic marker, cliticized at the right of the topicalized term (Montaut 2012). The non-thematizing functions of the clitic, depending on its scope in the sentence, will be described in section 3.

\section{To as a thematic particle}

\footnotetext{
3 Whether to belongs to the protasis or to the apodosis is a real question: it is traditionally considered to belong to the protasis (as correlatives in general), yet it cannot be omitted if the protasis is suspended.

4 The notions of fictive landmark ("repère fictive"), entailment ("entraînement"), scanning ("parcours") and access path ("chemin d'accès") are borrowed from Culioli (1999). Conditionals are considered in Culioli's model as involving "bifurcation" from one possible path to the other.

5 The Sanskrit pronominal basis $t a$ - displays in certain flexions and genders a form in $s a$ - (sah 'he', tat 'it'), a form (Hindi so) which is still used in Hindi as an adverbial coordinator ('then', 'so') and has long been used as a correlator for relative clauses (Montaut 2012.)
} 
When the particle to is a clitic which forms a single accentual word with the term at its left, a word which can always be followed by a brief pause, it behaves mostly as a topic marker.

$\begin{array}{llrll}\text { (3) } & \text { ajkal to } & \bar{a} p & \text { akele } & \text { hain } \\ \text { nowadays to } & 2 \mathrm{H} & \text { alone } & \text { be.PRES.PL } \\ \text { 'These days, you are alone' } & \end{array}$

In (3), the intonation shows an ascending tone on to which bears the accent in the "word" $\overline{a j k a l}$ to which is the topic, while the remaining of the clause (comment) is intoned in lower pitch

\subsection{Theme, rheme and focus in Hindi}

Whether according to Chafe (1976)'s more cognitive definition based on the "given" and "known", then Gundel \& al. (1993)'s finer definition of "givenness", including "semiactivated" and "inferred", or to Bonnot $(1990,2006)$ and Guimier (1999)'s more formal definition based on the position and intonation, the topic or theme comes first in the sequence. Although significant research has been carried out during the last decades on focus and focalization in Hindi, mainly within the generative frame, practically none is available on the theme. I am using the term "focus" in its restricted meaning, and not in reference to the part of the sentence which comments the theme, which I will label rheme or rhematic content. A focalized constituent within the rheme is marked by its linguistic prominence (emphasis) by means of intonational or accentual marking, specific word ordering or morpho-syntactic devices such as cleft sentence or focus particles (Wlodarczik 2006, François \& Lacher-Dutour 2003). 6

A statement may have no theme nor focus, and be an entirely rhematic content, what is currently designed as a thetic sentence ("it is two o' clock"). ${ }^{7}$ In Hindi, an ergative head final language usually considered with SOV order, ${ }^{8}$ the equivalent entirely rhematic statement (do baj gae, two strike went) shows no pause and no accentual pitch. Similarly in (4a), uttered in answer to a medical inquiry, is entirely rhematic:

$\begin{array}{llll}\text { (4) a mainne bacpan } & \text { se ainak } & \text { rakhīhai } \\ & \text { 1SG.ERG childhood from glasses } & \text { put PFT } \\ & \text { 'I wear glasses since my childhood, }\end{array}$

Although the theme is essentially marked by its position, always initial, and by the possibility of marking a pause after the thematized expression, not all fronted constituents are thematic, since a subject placed between the object and the verb is in the focus position without necessarily the first constituent being a theme. In (4b), uttered as a polemical answer to the previous statement "I don't see any around", the object ainak "glasses" is not a theme

\footnotetext{
6 This restricted meaning is distinguished from the "general" or psychological meaning of focus of attention by Gundel \& al. (1993: 279, note 1, after Hajičova). Focus in the psychological/cognitive meaning (focus of attention) is equivalent to the rhematic content, but not in its restricted meaning (linguistic focus).

7 As clearly stated by Gutierrez-Alvares (2003: 17): "Rheme is present in all statements. Focus is not, and it requires a specific marking: it is always a marked function".

8 It has postpositions and no prepositions, goal complements always precede the verb, and only the SOV order allows all syntactic transformations are available. Some scholars (Mohanan 1994) consider Hindi as a free order language because all constituents can shift position without morpho-syntactic restructuration. but they mention "scrambling", which implicitly refers to some basic or dominant order.
} 
although first in the sequence, with the subject in the second place as a contrastive focus. But it is in (4c), in answer to "where are my glasses, everything gets lost in this house", the object ainak, with the same position, is a theme:

(4) b ainak tūne lagā rakhīhai yā mainne?

glasses 2S.ERG place put PFT or 1SG.ERG

'Is it you who is wearing glasses or I?'

(4) c ainak kal rāt mez par rakhīthī

glasses yesterday night table on put PPFT

'The glasses, you had put them on the table yesterday night'

Detached after the verb, the same object behaves as a delayed theme or post rheme ("antitopic" in Chafe 1976, "mneme" in Fernandez-Vest 2004 and in this volume) in the same context as (4c):

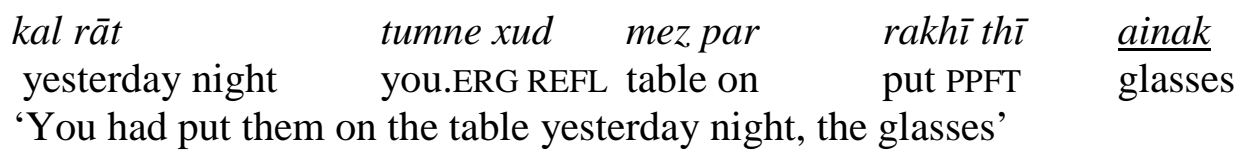

Regarding the intonation pattern, sentences with a focalized constituent does not make a significant difference, as opposed to better studied languages such as English or French. The constituents in Hindi or Bengali are in a strict down step relationship regardless of word order (Lahiri 1999), probably because of the prominence of lexical stress (Ohala 1986). The only difference observed by Patil et al. (2008) is that pitch excursion and duration are higher in OSV sentences where the subject is focused compared to SOV sentences, and focus constituents show greater pitch excursion and longer duration. But no acoustic study is available for OSV sentences where the object is thematized.

It is often considered that "scrambling" results in adding definiteness to all constituents in Hindi, ${ }^{9}$ but the reason why the object is always definite in $(5 b)$ is that a term shifted to the initial position is potentially a theme and a theme is necessarily definite (on the other hand, a term shifted to the preverbal position is focalized and potentially definite):

(5) a

sunār

ne laRkī ko

$h \bar{a} r$

bhejā

jeweller ERG girl DAT necklace send.PFV.MSG

'The/?a jeweller sent the/a necklace to the/a girl'

(5) $\mathrm{b}$

$\begin{array}{lllll}\text { hār sunār ne laRki ko bhejā } \\ \text { necklace jeweller ERG girl DAT } & \text { sent } \\ \text { 'The jeweller sent the/*a necklace to the girl'10 } & \end{array}$

\subsection{Constructing a theme as contrastive}

Practically all lexical categories (noun, adjective, adverb, verb) may be thematized by the particle to in all syntactic functions (subject, object, beneficiary, oblique, attribute, predicate). Since a topic does not require to for behaving as such - position and accent are sufficient indicators of thematization -, it must be hypothesized that to constructs a particular kind of theme, intuitively perceived as "contrastive" or "emphatic" (McGregor 1972: 141). This

\footnotetext{
${ }^{9}$ Dvivedi (1994) however shows that contrastive focuses may, exceptionally, remain indefinite.

${ }^{10}$ Example from Mohanan \& Mohanan (1994 : 169). In fact, $h \bar{a} r$ 'necklace' is thematized in (5b) with a possible pause after $h \bar{a} r$, and the literal translation would rather be 'the necklace, the jeweller sent it to the girl' ('to a girl' would correspond to Hindi kisī laRkī ko, INDEF girl DAT).
} 
section shows that this operation involves either a contrast with another term belonging to the same paradigm, or a contrast in judgements on the same term.

\subsubsection{Contrast with other elements belonging to the same paradigm}

Example (3) above makes the temporal frame ( $\bar{a} j k a l$ 'nowadays') a contrastive theme, implicitly suggesting that before or after, the situation was/will be different: in the narrative, it corresponds to the moment when the addressee gets up to take leave and the speaker gives the answer in (3), suggesting that he should stay some more since "he is alone", and implicitly there is nobody home waiting for him these days, as opposed to last week or next week for instance. To makes the adverb a theme by actualizing the relation which the other terms of the same paradigm could have had with the implicit meaning: usually you are not free, the fact that you are alone nowadays is a good occasion not to miss. The answer given ("I am alone/alone, sure, but I still must absolutely be back home" in example (13) below) makes this intended meaning ("you should stay longer as usual") clear. In (6), the elements of the paradigm contrasting with the to-topic are explicit in the previous context: "give me your school books for a few hours, I forgot mine". The particle to here builds the item as contrasting with the other items (available now) of the paradigm of school books:

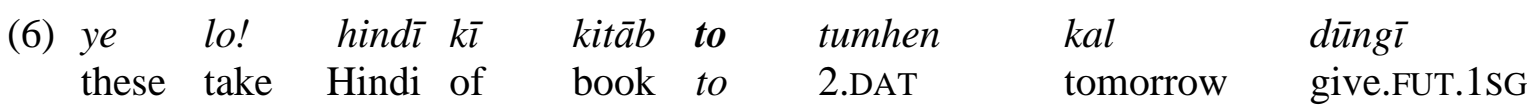

'Take these! The Hindi book, I will give it to you tomorrow'

In (7), the possible substitutable terms in the paradigm out of which mujhe "to me" is contrastively selected are implicit:
(7) mujhe
to usne
kuch
nahīn diyā
1SG.DAT to 3SG.ERG something NEG gave
'(But) to me (I, as far as I am concerned) she has not given me anything'

Example (7) occurs as an answer to the description of $\mathrm{X}$ as extremely generous. The speaker reacts by representing himself (theme), as somebody who, contrary to the others, has never benefited from it. The operation consists in constructing the topic in contrast with the implicit paradigm of the other terms which could illustrate the generosity of $\mathrm{X}$, and thus amounts to contest the previous representation of a supposedly universal giver. Its argumentative meaning derives from its basic function, which consists in making its scope as a contrastive theme.

An even more polemical meaning appears in (8) where the thematized numeral tinn "three" is followed by to. The speaker B, a Muslim, in a train, answers a question from A, a Hindu, which does not really aim at getting an information, since A only seeks to blame his own wife for her stupidity in not going and sit in the "ladies compartment". A's rhetorical question aims at having his judgment on his wife cautioned by the other travellers.

(8) a A-- kō̄ aur aurat bhī hai baiThīhū̄ mardāne Dabbe men INDEF other woman evenis seated being male compartment in A- 'Is there any another woman sitting in the men compartment ?'
$B$-- tin to mujhe
nazar $\bar{a}$
rahī hain
three to 1SG.DAT look come PROG PRES

B- 'There are three (you can't deny) I can see' 
The term tinn 'three' is constructed by to as contrasting with the number presupposed by A's rhetoric, zero (none would be so stupid as not to travel in the ladies compartment). When A answers that he sees three of them, he emphasizes the dishonesty of B in the count (you want us to believe that there are none but there are three I can see), and so dismisses his rhetoric: hence the polemical interpretation of to here, followed by a hot discussion between both A and B. If A had answered by a thematic "I"-to, contrasting then his own vision to B's vision, he would simply have opposed his own count to B's count, with a milder polemical impact:

$$
\begin{aligned}
& \text { mujhe to tīn nazar } \bar{a} \text { rahīhain } \\
& \text { 1SG.DAT to three look come PROG PRES } \\
& \text { 'As for me I (But if you ask me) I can see three of them' }
\end{aligned}
$$

And if he had simply uttered $(8 \mathrm{c})$ without the particle to, the statement would have meant that B interprets A's question as a real question, devoid of polemic undertones, to which B could give a factual answer. Such an answer, at least strange in the above context, is natural after a real question like "how many of them do you see?"

mujhe tīn nazar $\bar{a}$ rahì hain
1SG.DAT three look come PROG PRES
'I can see three of them'

In the context of a quite aggressive discussion between Hindu and Muslim travellers just before the Partition of India, (8a) has the expected impact of a very polemic statement: it discards the Hindu husband's rhetoric about the stupidity of his wife. ${ }^{11}$ And indeed the further context shows that B has only wished to contest the Hindu husband's tyranny over his wife, a tyranny he wants to emphasize because he is a Muslim and the Muslims are generally the ones blamed for depriving their women of freedom. This polemical use of to, whose efficiency is immediately perceptible in the dialogue following this sequence (violent quarrel about women's freedom in both communities), is in conformity with the logic of the particle's meaning, always more or less argumentative.

\subsubsection{To as a re-qualification of an already mentioned term}

When to has scope over a term which repeats an already mentioned term (either or not a previous theme), it re-qualifies it. Shapiro (1999: 182 - 3) interprets this "reiteration" as "sustaining" a previous interpretation, or "in contradistinction to a parallel form that is operative in the discourse at hand". Yet this "sustaining", echoing of McGregor "emphasis", always implies a re-qualification. In (9) for instance, the attribute "shameless", part of the previous statement by A in a non topical position (attribute), is repeated in B's statement:

$\begin{array}{llllll}\text { (9) A. ye log besharam hain. B. } & \text { besharam to ap hain! } \\ \text { these people shameless are } & & \text { shameless to you are } \\ \text { 'These people are shameless'. } & & \text { 'Shamelessness is rather yours!' }\end{array}$

11 The wife (C) consequently gets over her own shyness to protest and then the husband (A) overtly insults her, finding no longer escape in pseudo-rhetorical arguments since they have been torn out by (8a):

C-zanāne Dabbe men kō̄ bandā na pardā! main kaise baiTh jātī?

A - tū chup karegī ki nahīn? Bevakūf!

' $\mathrm{C}-$ There is not a soul in the ladies compartment! How could I sit there?

A- Will you shut up (or not)? Idiot!' 
The term besharam "shameless", formerly part of the comment, is promoted by B in the theme position, but a theme re-qualified in its relation with its referent since the referent is now the opposite group (it is you, not us, who are shameless): the already given term, when thematized with $t o$, is redefined as a different type of shamelessness in relation to the new subject.

In (10), to occurs three times, and is used each time in order to re-qualify a term which has been previously introduced by another speaker with a different viewpoint. Two parents are complaining about the Hindi teacher of their daughter and the stupid homework she has required, an essay on hunger:

(10) MOTHER -- itnā sārā homework, vah bhī hind̄̄ men! Ab hind̄̄ bhī kō̄ sabjekt rah gayā hai, ājkal ke zamāne men! islie main kahtī hūn iskī hind̄̄ k̄̄ Madam ko haTvā do!

'So much of homework! And in Hindi on top of that! As if Hindi was still a real subject nowadays! That's why I am asking you to have this Hindi Madam (teacher) fired!'

DAUGHTER -- nahīn Pāpā, please aisā mat karnā ! merī hindī kī Madam bahut kyūT hai. 'No, daddy, please, don't do that! My Hindi teacher is very cute'

Vah to hindī ki lagtī hì nahīn, bahut smart hai, ekdam!

3SG to hindi of seem just NEG much smart be.PRES.3SG totally

She (you know) just does not look like a Hindi (teacher) at all, she is very smart, absolutely!

[Both parents discuss the question of homework between themselves]

FATHER - ham apnī biTiyā ke lie ek aisā tutor rakh lenge jo sārā homwork phaTāphaT kar diy $\bar{a}$ kareg $\bar{a}$

Well, we will find a tutor for our daughter who will get the homework done in a minute. MOTHER - Tutor se to computer behter. (...) Computer yes, tutor no. Never! Tutor badmāsh hote hain. Always! Merā ek tutor hotā thā, very bad.

A tutor [do you realize what a tutor means ?], a computer would do better (...). Computor yes, tutor no. Never! All tutors are wrecks. I used to have a tutor, very bad .

FATHER - (...) khair, is māmle ke bāre men main pūchtāch phir kabhī karūngâ. Apnī biTiya $\bar{a}$ ke lie to ham lady tutor hī rakhenge

(...) Well, I will look in that matter some other time. [But] For our daughter [at any rate] we will find a lady tutor [not a man])

In the first sequence, the requalification of the same referent ( $v a h$ to thematize a previous subject "my Hindi teacher" which itself requalifies a previous object "her Hindi Madam") amounts to construct the theme as contrastive in relation to its occurrence in the mother's statement. The occurrence of the referent in the daughter's talk without to ("my Hindi teacher"), already associated with a positive evaluation contrary to the mother's viewpoint, only serves as an argument given by the daughter for not firing her Hindi teacher. The next sentence with to presents the positive qualification as relevant per se, in total opposition with the other speaker's viewpoint. To expresses the discrepancy between an initial viewpoint on a class (the type: Hindi teacher, generally considered as dull) and an individual (who gives too much work) as well as a different viewpoint on a particular individual belonging to the class but not fitting the usual qualification.

The second sequence of the dialogue opens with a proposal by the father to substitute a tutor for school classes in Hindi: what he emphasizes is the competence of the tutor in helping for homework, the idea of having a tutor is itself taken for granted. And it is this very idea (presupposition) which the mother opposes, by shifting the debate to tutors in general and 
then to one in particular, her former tutor. Attached to "tutor" in the mother's discourse, to makes it a theme which negatively contrasts with the implicitly positive opinion on tutors expressed by the other speaker, the father. Without to, the statement would have only expressed a mere comparison between various school props. To gets the class of tutors questioned, hence the following shift towards personal (bad) memories.

And when the father tries to come back to the initial question, it is again to (third occurrence) that brings back to the foreground the main theme ("our daughter"). Thematizing "daughter" is a device used for going on with the initial problem - how to help the girl while contrasting the relation girl-tutor with the relation mother-tutor previously commented by the mother: contrary to the previous relation, bad because of male tutors, father's statement qualifies positively the relation daughter-tutor (lady tutor): to does not contrast a distinct viewpoint on the daughter, but the relation 'daughter-tutor' with the parallel relation 'pupiltutor' represented in the viewpoint of previous speaker (mother).

Example (11), also exhibits a conflict in viewpoints, on the predicative notion this time: B and $\mathrm{C}$ have just expressed that they do not understand what $\mathrm{C}$ means (hence asking for more information), whereas $\mathrm{C}$ questions his own statement as potentially dubious (regarding his own understanding).

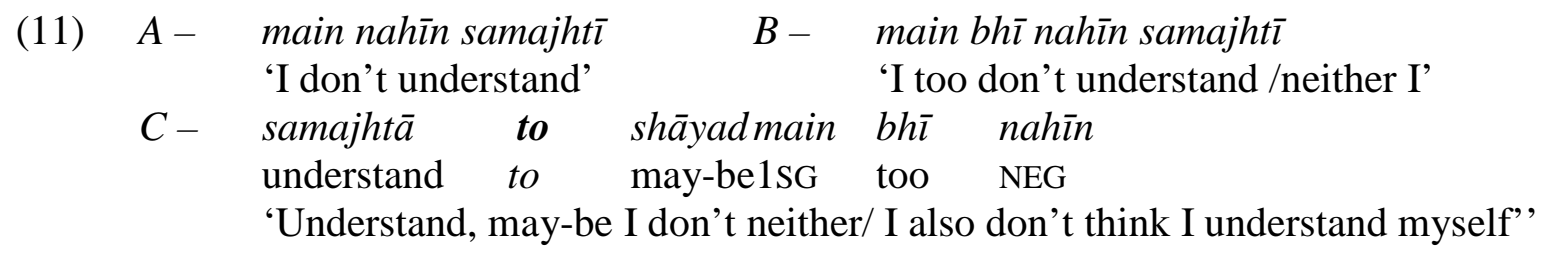

But it frequently happens that the particle, although placed after the first segment of the statement, has scope on the whole sentence: in this case to re-qualifies the statement as a whole, most of the time with polemic intentions.

\section{The argumentative particle}

The formal difference between thematizing and non thematizing uses of discourse particle to relies not so much on the position of to than on the unavailability of any pause after the term on which the particle cliticizes. The position however may be relevant in certain cases: when to is clause final, it is always strongly argumentative.

\subsection{Denying or shifting the relevance of a previous argument}

The particle to, with scope on the whole statement, usually consists in limiting the relevance of an argument previously proposed by the other speaker, while pretending to confirm it. To rephrase the argument with to amounts to giving this argument a limited or factual confirmation, in order to better deny its wider or real relevance. In (12) for instance, a statement by $\mathrm{B}$, to has scope over a clause $\mathrm{P}$ which rephrases the clause $\mathrm{P}$ ' previously stated by speaker A, "speak the truth": no segmentation is possible and to receives a light stress (stronger stress on $h \vec{l}$ ), the meaning intended by B amounts to agree with A but only in order to relativize the relevance of A's argument (sure you are right, but it is not the point). 
(12) A - shaharī log baRe beìmān hote hain. Marad kyā aur aurat kyā. Hindū kyā aur musalmān kyā. Sāre fitne-fasād shaharon se hì shurū hote hain. kyon bābājî̀ main jhüTh bol rahā hün yā sac?

'The city folk is all very dishonest. Men and women alike. Hindus and Muslims alike. All communal riots start in cities. Right, Baba-ji ? Do I speak lie or truth ?'

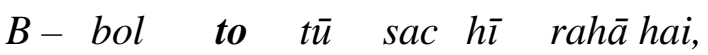

speak to you true just PROG PRES

'You (indeed) speak true (Sure you are right),

par isse bhī baRā sac yah hai ki insāf na shahar men na gānv men. Insāf to ${ }^{12}$ tum dekh lenā Pakistān men bhī nahīn hogā.

but there is a bigger truth than that, and this is that justice is neither in cities or villages. Justice, you will see, you won't find it either in Pakistan'

The fronted thematized verb ( $b o l$ 'tell'), in the strongly marked order V-to-S-O-aux, is not the simple quote of A's utterance, which is unmarked in its ordering (SOV) with the same object ( $s a c$ 'truth'). The new mapping within to... hi does not simply discard the alternative ("or wrong") nor does it bring a different viewpoint on the predicate or the clause P, whose validity is not questioned. But if $\mathrm{B}$ agrees with $\mathrm{A}$ on the initial location of communal violence, he does so in order to signal that this "truth" has little relevance (to) in the present discussion. B implicitly disqualifies A's interpretation of facts, while granting him the confirmation he rhetorically asked for ("right or wrong": you can't say I am not right). But he grants him such a confirmation ("sure you are right") only for the sake of shifting from P1 to $\mathrm{P} 2$ : the real problem is not your being right on the initiation of violence $(\mathrm{P} 1)$ but to deal with justice (P2). B does not enter in A's rhetoric and to marks this refusal to accept A's premises while accepting only the conclusions.

Similarly, in (13), the continuation of (3) supra, B in the first clause, with the same structure as (12), qualifies A's argument as weakly relevant, and in the second adversative clause provides another argument as crucially relevant, in contradiction to A's request:

$$
\begin{gathered}
\text { (13) A-- ajjkal to } \bar{a} p \text { akele hain... B-akelā to hün, lekin ghar to jānā hì hai } \\
\text { nowadaysto } 2 \mathrm{H} \text { alone are alone to am but house to go hi is } \\
\text { '- These days you are alone... -- Sure I am alone, but I really must go home' }
\end{gathered}
$$

In the first (underlined) clause of B's answer, the absence of to would result in a rather strange meaning in this context, since A was not asking for a confirmation but was using the argument to convince B to stay longer. In B's second sentence, to... hi in an adversative clause makes the clause a crucially relevant argument in countering A's offer.

\subsection{Making the clause a crucial discursive argument}

Discursive cruciality is involved in the last clause of last example (13) ghar to jânâ hî hai 'I really have to go home'. Although apparently opposed to the meaning of to in the first clause of the same example (denial of relevance), it nonetheless participates in a similar operation: speaker A provides a new element in the discussion, something that the addressee had either not thought of or had not wished to consider. What is at stake is the promotion of the propositional content within a perspective opposed to the addressee's view, for which the proposal is either not relevant or not conceivable. Such an operation is then symmetrical to

\footnotetext{
12 To here is a topic particle which backs the topic of justice (in contrast to previously mentioned: justice in God's realm =Pakistan) after the digression about cities/villages.
} 
the denial of relevance, where $\mathrm{P}$ was relevant for speaker $\mathrm{A}$ and not for speaker $\mathrm{B}$. When this operation occurs in non adversative contexts (of the type 'sure, but'), the salience intuitively perceived in to-statements is due to the fact that such statements are constructed in opposition to a previous implicit assumption of speaker A. Hence their objection-like character instead of simple assertions. The series of answers to the suggestion 'let us go and have some tea' given by Lakshmi Bai (1977) as examples of "assertive particle" can be explained in this way:

$\begin{array}{lllll}\text { mere pass to bas das paise hain } \\ \text { 1SG.GEN at to only ten paise are } \\ \text { 'I have only ten pence with me [not enough]' } \\ \text { kanTinto band ho gaya a hog } \bar{a} & \text { abhi } \bar{l}\end{array}$

cantineto closed be go.PFV PRESUMPTIVE right.now

'The cantine must be closed by now'

$\begin{array}{llllll}a b h \bar{\imath} & \text { to } & \text { tin } & \text { nahīn baje hain } & \\ \text { right.now to three NEG ring PFT } & \\ \text { 'It is not yet three o'clock [too early] } & & \\ \text { das minaT to } & \text { kăm } & \text { karne } & \text { do } & \text { bhāi } \\ \text { ten minutes to } & \text { work } & \text { do } & \text { let } & \text { brother }\end{array}$

'Let us work ten minutes more, brother'

Each of the answers $(14 \mathrm{a}-\mathrm{d})$ represents according to Lakshmi Bai the choice of the speaker among various alternatives, and to asserts this choice. However, a single speaker does not really select one by dismissing the other alternatives, and the 'assertive force' is the result of the inter-subjective relation involved in the whole series as an answer to a proposal which the speaker wishes to discard. Speaker A in (14a) signals to speaker B (let us have some tea) something of which B was not aware (not enough money, closing time, unfinished work), which makes it difficult to obey the request and therefore acts as an indirect objection or refusal. To here behaves as a request for taking into account what the speaker valuates as a crucial argument that has been neglected by the addressee. Hence the possible translations opening with "but you know", "the problem is", "but"...

When the discourse particle to has scope on a proposal already stated by a previous speaker, it denies it full (or any) relevance. When it has scope on a proposal which is new, it builds the relevance of this new $\mathrm{P}$ in contradiction with what the speaker thinks is the viewpoint of the other speaker.

\subsection{Final to: winning over the other's reluctance}

I have shown elsewhere that preverbal to in the last syntagm of questions amounts to checking if the proposition has been successfully realized (in conformity with the speaker's expectations and against the obvious difficulties barring access to that realization ("let us hope that P"). ${ }^{13}$

In a postverbal position, mostly after a verb in the imperative, the particle to acquires such a specific meaning that it is often deemed a quasi homonym of the "assertive" particle (Lakshmi Bai 1977: 73; Shapiro 1999: 186).

\section{(15)batāo to !}

13 Montaut (2002). Such a use is idiomatized in the expression āp acche to hain? 'How are you/hope you are fine?' [you well to are] but still differs from the same statement uttered without to by its contextual constraints: it is natural only when the speaker has not seen the person he greets since a long time, or has got bad news, or thinks he may not be so well... example of the meaning "insistence" in McGregor. 
tell to

'But tell it (now)! Come on, why don't you tell? Will you finally tell it?'

Statement (15) strongly differs from its counterpart without to and requires a specific context: it echoes a strong reluctance on the part of the addressee, or at least the speaker's anticipation of such reluctance. ${ }^{14}$ Example (16) shows concrete evidence of B's reluctance:

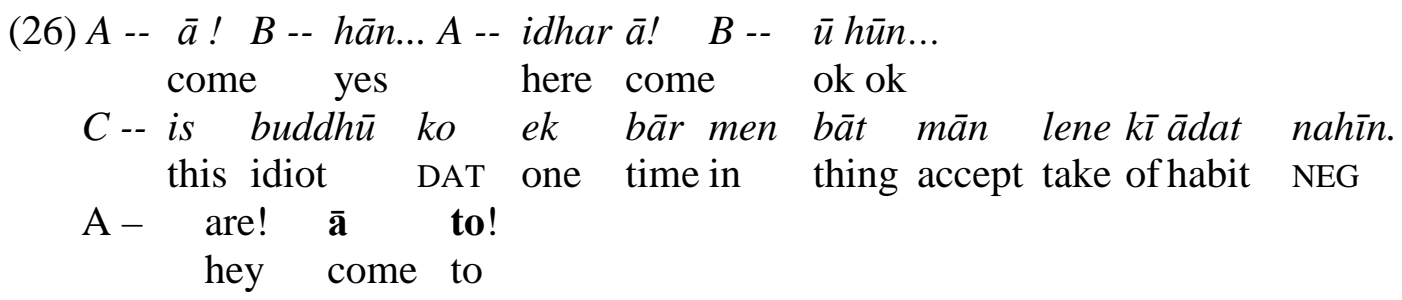

'A - Come! B - Ya... A - Come here! B - Ok ok...C - This idiot is not used to obey at the first time. A - Hey you! you do come! [what are you waiting for!/ will you move your ass?]'

When A utters the last sentence (with to), he has already ordered B twice to come, without to, and this order has not yet been fulfilled. Only in the third utterance of the same order, once fully aware of B's reluctant behaviour, A uses to after the order verb. The intuitive perception of insistence results in reality from the feature "unwillingness" imputed by A to B.

Far from a mere emphasis, stylistically optional, such examples show that the particle to operates systematically in constructing $\mathrm{P}$ as countering a non-P imputed to the addressee. With to, an order then conjures up the risk of not reaching its goal, and at the same time emphasizes the addressee's reluctant behaviour. Here again, the meaning of to stems from contrastive and even conflicting attitudes of both partners. Similarly, phrasal nahin ('no') in answers to P, when followed by to (nahin to) acquires its "emphasis" from the fact that the speaker refutes an assumption he imputes to the addressee.

\section{Conclusions}

The very high frequency of the occurrences of to, particularly remarkable in oral interaction, as well as the variety of its meanings and functions, may be correlated to the limited number of words behaving as discourse particles in Hindi. ${ }^{15}$ This contrasts with the situation in Germanic languages which display far more numerous discourse particles, a dozen in German (Weydt 1969) with more than one equivalent for each in Serbo-croatian (Diewald and Krescic 2010), in which each particle has consequently a more restricted usage.

In spite of the apparent heterogeneity of the meanings involved in the data studied, one can argue that the multiple surface meanings and functions of the discourse particle to obey a single basic meaning, although not concretely semantic but rather pertaining to an abstract operation. This basic meaning consists in triggering an operation which deals with alterity ("altérité": 'otherness'), at various levels: to seems to convey the speaker's judgment on a

\footnotetext{
14 A weaker (because idiomatized) expression of the same meaning is still associated to the common polite way of welcoming a visitor baiThie to (sit-down to) 'why don't you sit down'.

15 As evidenced by the various examples: (13), (20), (21), (22), (27) are from Bhūkh āg hai (KB Vaid, Hunger is fire), contemporary theatre, or (11), (14), (15), (16), from Guzrā huā zamānā (KB Vaid, The broken Mirror [lit. Time past]), a contemporary Partition novel, or from recorded conversations (Standard Hindi, middle class, 40-60 years old informants, Delhi). The other two commonly used discourse particles are $h \bar{\imath}$ (focus particle, particularly in restricted focus) and $b h \bar{\imath}$ 'even'.
} 
term or sequence on which it has scope, in such a way that to-P triggers the implicit or explicit representation of $\mathrm{P}^{\prime}\left(\mathrm{P}^{\prime}\right.$ : non $\mathrm{P}$ or other than $\left.\mathrm{P}\right)$.

When to is a thematic particle, $\mathrm{P}$ is the thematized term and $\mathrm{P}$ ' either refers to other members of the same paradigm where $\mathrm{P}$ belongs, or it constructs a different relation between $\mathrm{P}$ and its rheme, or a viewpoint on $\mathrm{P}$ differing from the viewpoint previously expressed by (or attributed to) the other speaker (re-qualification). This thematic function has no parallel in the Germanic discourse particles (more often called modal particles or Abtönungspartikel), since their common characteristic is to have for "focus the relational category of discourse rheme in a sentence", and to have "scope over the whole VP" (Abraham 1991: 356). In Hindi the nonthematic to only has scope over the whole sentence.

In such cases, that is, in Hindi, in sentences entirely rhematic, structured as thetic or focus sentences, to presents the whole statement on which it has scope as a correction of another distinct viewpoint: either a new argument is presented as countering an initial proposal, or a proposal already voiced is presented with weaker relevance or no relevance, or (in pre- or postverbal positions) to aims at rejecting an opposite eventuality (conjuring a fear, dismissing a fictive assumption, winning over an anticipated reluctance from the other speaker). The operation triggered by the discourse particle to always involves inter-subjectivity, since it negotiates with the other's viewpoint, distinct from and often conflicting with the utterer's viewpoint. ${ }^{16}$ This prerequisite of inter-subjectivity is paralleled by the behaviour of Germanic modal particles as described in terms of dialogic interaction in Weydt (2006) or grounding and common grounds in Fischer (2007), Diewald and Krescic (2010) or Bross (2012): the speaker acknowledges what the hearer thinks as a common ground for anchoring his/her proposal. The specificity of Hindi to is that this inter-subjective interaction rarely fosters conviviality or connivance since it basically involves conflicting or at least diverging viewpoints.

This orientation is compatible with the origin of the word, initially a pronominal basis related to the sphere of non-ego. As for the conjunction to, when it is a correlative, to, which is directly related to the anaphoric pronoun, correlates the apodosis to a conditional, acting both as an anaphoric device and as a selecting a given path among others; when it coordinates two discourse sequences ('then'), it opens a new scenario resulting yet distinct from the previous discourse sequence.

The behaviour and meaning of to as a discourse particle certainly differ from its syntactic meanings: they are highly diversified and often involve polemical values. Yet they form a constellation of meanings and uses whose consistency becomes clear as soon as the operation at stake is analyzed on the basis of interactive contexts; besides, they are not totally disconnected from the grammatical word. ${ }^{17}$ But the discourse particle always involves intersubjectivity, whereas the conjunction is not sensitive to it. The above study is of course only a fist attempt to disentangle the meanings and functions of to in interactive situations, and finer grain studies are still awaited, particularly regarding the exact intonational contours in the various scopes (thematizing vs non-thematizing) of the particle.

Abraham, Werner. 1991. The Grammaticization of the German Modal Particles. In Edith

\footnotetext{
16 As opposed to the uncontroversial meaning of the focus marker derived from the tag question marker in Even (Matic, this volume, example 26b). There is probably a logical correlation between the fact that the focus marking element produces uncontroversial common ground in the inter-subjective relation of speaker A and B, whereas the topic marking element emphasizes diverging view points in the interaction.

17 Which is also true of the Russian particle to, analyzed by Bonnot (1990), equally issued from the same Indo-European pronominal basis. Russian to has numerous uses comparable to those of Hindi to, but not the correlative one nor the meanings observed in section 3.2.
} 
Traugott \& Berndt Heine (eds.). Approaches to Grammaticalization II, 331-80. Amsterdam: Benjamins.

Bonnot, Christine. 1990. La Particule to et la polémique cachée en russe moderne. A propos du statut énonciatif du thème. Revue des Etudes Slaves LXII-2: 67-75.

Bonnot, Christine. 2006. Lorsque la focalisation porte sur l'ensemble de la relation prédicative : les énoncés à accent non final en russe moderne. In Wlodarczik Hélène \& André (eds.). La focalisation dans les langues, 135-148. Paris : L'Harmattan.

Bril, Isabelle \& Rebuschi, Georges. 2006. Coordination et subordination, Typologie et modélisation. Gap: Ophrys.

Bross, Fabian. 2012. German modal particles and the common ground. Helikon. A Multidisciplinary Online Journal, 2 : 182-209.

Culioli, Antoine. 1999. Pour une linguistique de l'énonciation 2. Formalisation et opérations de repérage. Gap: Ophrys.

Diewald, Gabriele \& Marijana Kresic. 2010. Ein übereinzelsprachliches kontrastives Beschreibungsmodell für Partikelbedeutungen Linguistik Online 44-4/2010.

Fischer, Kerstin. 2007. Grounding and common ground: modal particles and their translation equivalents, in Anita Fletzer \& Kirsten Fischer (eds.). Lexical Markers of common ground, Studies in Pragmatics 3, 44-66. Amsterdam: Elsevier.

Dvivedi, Veenita. 1994. Topicalization in Hindi and the Correlative Construction. In Butt, M., T.H. King \& G. Ramchand (eds.). Theoretical Perspectives on Word Order in South Asian Languages, 91-118. Stanford : CSLI Publications.

Guimier, Claude (ed.). 1999. La Thématisation dans les langues. Bern: Peter Lang.

Fernandez-Vest, M.M. Jocelyne. 2004. Mnémème, Antitopic : Le post-rhème, de l'énoncé au texte. In Fernandez-Vest, M.M. J. \& Sh. Carter-Thomas (eds.). Structure informationnelle et particules énonciatives: Essai de Typologie, 65-104. Paris: L'Harmattan.

Fernandez-Vest, M. M. Jocelyne. Detachment linguistics and information grammar of oral languages. In this volume.

François, Jacques \& Lacher-Dutour, Anne. 2003. Fonction et moyens de la focalisation à travers les langues. Mémoires de la Société de Linguistique de Paris. Leuven : Peeters.

Gundel, Jeanette K., Helberg, Nancy \& Zadarsk, Ron. 1993. Cognitive Status and the Form of Referring Expressions in Discourse. Language 69-2: 274-307.

Gutierres-Ordonez, Salvador. 2006. Focalisation, Thématisation, Topicalisation. In Wlodarczik, Hélène \& André (eds.). La focalisation dans les langues, 11-26. Paris : L'Harmattan.

Haiman, John. 1978. Conditional are Topics. Language 54-3: 564-89.

Haspelmath, Martin (ed.). 2008. Language Typology and Language Universals.

Berlin/Amsterdam: de Gruyter.

Haspelmath, Martin (ed.). 2004. Coordinating Constructions. Typological Studies in Language. Amsterdam: John Benjamins.

Kellogg, Rev. S.H. 1938 [1856]. A Grammar of the Hindi Language. London: Paul Kegan.

Lahiri, Aditi \& Jennifer Fitzpatrick-Cole. 1999. Emphatic clitics and focus intonation in Bengali. In R. Kager \& W. Zonneveld (eds.). Phrasal Phonology, 119_144. Nijmegen: University of Nijmegen Press.

Lakshmi Bai B. 1977. Syntax and Semantics of the Particle To in Hindi. Osmania Papers in Linguistics 3: 64-75.

Matic, Dejan. Tag questions and focus markers. In this volume.

McGregor, R. S. 1972. An Outline of Hindi Grammar. Delhi: Oxford University Press.

Mohanan, Tara \& K. P. Mohanan. 1994. Issues in Word Order. In Mariam Butt, Tracy H. King \& Gillian Ramchand (eds.). Theoretical Perspectives on Word Order in South Asian Languages, 153-184. Stanford : CSLI Publications:.

Montaut, Annie. 2002. La particule énonciative to en hindi/ourdou. Cahiers de Linguistique de 
l'INALCO 4 : 111-134.

Montaut, Annie. 2004. Hindi Grammar. Munchen : Lincom Europa.

Montaut, Annie. 2012. De l'anaphore à la subordination en passant par la corrélation, In Olga Inkova \& Pascale Haderman (eds.). La Corrélation, 193-213. Paris : Champion.

Ohala, Manjari. 1986. A Search for Acoustic Correlates in Hindi Stress. In Bh. Krishnamurti (ed.), South Asian Languages: Structure, Convergence and Diglossia, 81—90. Delhi: Motilal Banarsidass.

Patil, Umesh, Gerrit Kentner, Anja Gollrad, Frank Kügler, Caroline Féry \& Shravan Vasishth. 2008. Focus, Word Order and Intonation in Hindi. JSAL 1: 55-72.

Shapiro, Michael. 1999. Hindi to as discourse marker. In P. J. Mistry and Bharati Modi (eds.). Vidyopaasanaa: Studies in Honor of Harivallabh C. Bhayani, 179-89. Mumbai and Ahmedabad: Image Publications Pvt. Ltd.

Weydt, Harald. 1969. Abtönungspartikel. Die deutschen Modalwörter und ihre französischen Entsprechungen. Berlin West \& Zürich : Bad Homburg.

Weydt, Harald. 2006. What are particles good for? In Kirsten Fischer (ed.). Approaches to Discourse Particles. Amsterdam: Elsevier.

Wlodarczik, Hélène \& André Wlodarczik (eds.). 2006. La focalisation dans les langues. Paris : L'Harmattan.

\section{The discourse particle to and word ordering in Hindi: From grammar to discourse}

Annie Montaut Inalco USPC, SeDyL UMR 8202

\section{Abstract}

The Hindi particle to may be both a conjunction, which occurs in the initial position with the meaning "so, then", and a discourse particle, usually described as an intensive, or vaguely contrastive or emphatic device. Both have been treated as different units, and the discourse particle as several distinct (homonymous) words. The aim of the paper is to show that the diversity of the meanings and functions of the particle may be explained by a common abstract operation, realized in various ways according to the various specific contexts of occurrence, both syntactic and discursive. The first section briefly summarizes and interprets the main functions of grammatical to, as a coordinator and as a correlative, before I analyze the discourse particle, either with restricted scope and fixed position, as a topic marker (section 2), or with wider scope and no fixed position, as an argumentative particle (section $3)$.

Key words

Discourse particle, Hindi to, argumentation, thematization, inter-subjectivity, correlation

La particule hindi to peut être une conjonction (de coordination et de subordination), qui se place en première position et correspond aux sens «alors, donc», et un mot du discours, décrit d'ordinaire comme un intensif, ou un dispositif d' "emphase » vaguement contrastif. Les deux sont généralement considérés comme deux mots distincts, homonymes, tout comme le mot du discours est considéré comme recouvrant (au moins) deux particules distinctes, homonymes. En fait, les divers effets de sens attachés à la particule s'expliquent par une opération commune, qui se réalise différemment en fonction du contexte (position, portée). Par ailleurs les fonctions du mot grammatical montrent en quoi il a pu se spécialiser parallèlement comme marqueur de thème. 